\title{
The transfection-induced overexpression of IGF-binding protein-4 affects the secretory activity of porcine ovarian granulosa cells and their response to hormones and IGF-I
}

\author{
A V Sirotkin, A V Makarevich, M R Corkins ${ }^{1}$, J Kotwica ${ }^{2}$ and J Bulla \\ Research Institute of Animal Production, 94992 Nitra, Slovakia \\ ${ }^{1}$ Riley Hospital for Children, University of Indiana, Indianapolis, Indiana 46202, USA \\ ${ }^{2}$ Institute of Animal Production and Food Research, 10-718 Olsztyn-Kortowo, Poland \\ (Requests for offprints should be addressed to A V Sirotkin, Laboratory of Endocrinology, Research \\ Institute of Animal Production, Hlohovská 2, 94992 Nitra, Slovakia; Email: sirotkin@vuzv.sk)
}

\begin{abstract}
The aim of our studies was to examine whether IGF-binding protein (IGFBP)-4 is involved in the control of the secretion of various ovarian substances and also the mediation of the effects of several hormones and growth factors on this secretion. For this purpose, we carried out the transfection of porcine granulosa cells with a cDNA sense construct, increasing IGFBP-4 synthesis. We then compared the release of IGFBP-3, progesterone, oxytocin and IGF-I by control and transfected cells cultured with and without porcine $\mathrm{LH}(100 \mathrm{ng} / \mathrm{ml})$, porcine GH $(100 \mathrm{ng} / \mathrm{ml})$, IGF-I $(10 \mathrm{ng} / \mathrm{ml})$, oxytocin $(10 \mathrm{ng} / \mathrm{ml})$ and estradiol-17 $\beta(100 \mathrm{ng} / \mathrm{ml})$. The concentration of IGFBP-4 produced was assessed using ligand blotting, and the release of progesterone, oxytocin, IGF-I and IGFBP-3 was evaluated using RIA/IRMA techniques.

It was observed that GH, IGF-I, estradiol, LH and oxytocin alter the progesterone, oxytocin, IGF-I and IGFBP-3 release by porcine ovarian granulosa cells. Transfection of these cells with an IBFBP-4 cDNA expression construct significantly increased the IGFBP-4 accumulation in cell-
\end{abstract}

conditioned medium. Furthermore, this transfection significantly reduced progesterone, oxytocin and IGFBP-3 release, and increased IGF-I output in cells cultured in the absence or presence of $\mathrm{GH}$, IGF-I, estradiol and LH. The addition of oxytocin, but not of other tested substances, fully or partially prevented the effects of IGFBP-4 overexpression on IGFBP-3, IGF-I, but not on progesterone release.

The present results suggested that IGFBP-4, as well as GH, IGF-I, estradiol, LH and oxytocin, is a potent regulator of porcine ovarian steroid (progesterone), nonapeptide hormone (oxytocin), growth factor (IGF-I) and growth factor-binding protein (IGFBP-3) release. IGFBP-4 is an inhibitor of basal progesterone, oxytocin and IGFBP-3 release and a stimulator of IGF-I output by porcine ovarian cells. The action of IGFBP-4 on the ovary can be mediated by (1) inhibition of oxytocin release, (2) suppression of receptor/postreceptor events induced by other hormones and IGF-I and (3) stimulation of IGF-I release.

Fournal of Molecular Endocrinology (2001) 26, 241-248

\section{INTRODUCTION}

Insulin-like growth factor I (IGF-I) and IGFbinding proteins (IGFBPs) can be mediators of hormone action on the ovary (Erickson 1995, Spicer \& Echternkamp 1995, Yoshimura 1998, Schams et al. 1999). IGFBPs can affect target tissues by regulating the availability of free (bioactive) IGF-I or via IGF-I-independent mechanisms (Rajaram et al. 1997, Rechler \& Clemmons 1998). Production of both IGF-I and the six classic IGFBPs by mammalian ovarian cells has been shown previously (Grimes et al. 1994, Spicer \& Echternkamp 1995, Armstrong et al. 1996, Mihm et al. 1997, Schams et al. 1999), but the role that a particular IGFBP exerts in the control of ovarian functions remains to be elucidated.

There are several reports of the direct influence of the IGFBPs on ovarian functions. IGFBP-2, -3, -4 and -5 treatment, probably through the blockade of IGF-I and its receptors, can inhibit basal folliclestimulating hormone (FSH)- and IGF-I-induced 
ovulation, oocyte maturation and progesterone and estradiol secretion by human (Spicer \& Echternkamp 1995, Iwashita et al. 1996, Mason et al. 1998, Yoshimura 1998), rat (Spicer \& Echternkamp 1995, Putowski et al. 1997, Yoshimura 1998), porcine (Samaras \& Hammond 1995) and bovine (Spicer et al. 1997, Spicer \& Chamberlain 1999) ovarian cells. The effect of IGFBPs on ovarian peptide hormones (for example, oxytocin), as well as the inter-relationships between different IGFBPs, has not been studied previously.

In different species the ovarian production of various IGFBPs can be inhibited by gonadotropic substances (luteinizing hormone (LH), FSH, growth hormone $(\mathrm{GH})$, IGF-I, oxytocin and estradiol; Grimes et al. 1994, Spicer \& Echternkamp 1995, Armstrong et al. 1996, Mihm et al. 1997, Putowski et al. 1997, Sirotkin et al. 1998, Sirotkin \& Makarevich 1999), although a stimulatory effect of LH on the production of IGFBP-4 (Armstrong et al. 1996) and its mRNA (Armstrong et al. 1998) in ruminant theca cells has also reported. These data indirectly suggest that these gonadotropic substances can affect ovarian cells through the regulation of both IGF-I and IGFBP production. This hypothesis was partially confirmed by direct evidence of the inhibition of the effects of FSH and IGF-I by IGFBP additions (see above). It remains unknown whether IGFBPs can modify and mediate the effects of other gonadotropic substances - LH, $\mathrm{GH}$, oxytocin and estradiol.

To understand the role of IGFBPs in the control of ovarian functions, only one approach to increase IGFBP levels - treatment with exogenous IGFBP has been used. An alternative way, overproduction of an endogenous IGFBP by cell transfection with a sense cDNA construct of an IGFBP, has previously been used only on non-ovarian cells (Cohen et al. 1993, Corkins et al. 1995, Park et al.1996), but not on ovarian cells.

The first aim of our in vitro experiments was to examine the effects of different gonadotropic substances on ovarian steroid, nonapeptide hormone, growth factor and growth factor-binding protein release by studying the effects of $\mathrm{LH}, \mathrm{GH}$, IGF-I, oxytocin and estradiol on the release of progesterone, oxytocin, IGF-I and IGFBP-3 by porcine granulosa cells. The second aim was to find out whether IGFBP-4 mediates the release of IGFBP-3 and other ovarian secretions and modifies the effects of the gonadotropic substances mentioned above. For this purpose, we carried out transfection of porcine granulosa cells with cDNA constructs increasing IGFBP-4 synthesis, and compared the release of IGFBP-3, progesterone, oxytocin and IGF-I by the control and transfected cells cultured with and without LH, GH, IGF-I, oxytocin and estradiol.

\section{MATERIALS AND METHODS}

\section{Gene constructs used}

The full-length cDNA for rat IGFBP-4 and IGFBP-3 was a gift from Dr S Shimasaki (The Whittier Institute for Diabetes and Endocrinology, La Jolla, CA, USA). The EcoRI fragments of the IGFBP-3 and -4 cDNA (Shimasaki et al. 1989) were ligated into EcoRI-digested pcDNA3 vector (Invitrogen, San Diego, CA, USA). After ligation, the DNA was used to transform DH5- $\alpha$ E. coli (GIBCO-BRL, Gaithersburg, MD, USA) and colonies were selected for ampicillin resistance. Plasmid minipreps were prepared to permit identification of the appropriate orientation of the cDNA insert (Corkins et al. 1995).

\section{Preparation, culture and processing of granulosa cells}

Granulosa cells were collected from the $2-5 \mathrm{~mm}$ diameter follicles from ovaries of Slovakian white gilts at 180 days of age, slaughtered at a local abattoir and processed as described previously (Sirotkin 1996, Sirotkin \& Makarevich 1999). After isolation and washing, the cell population was divided into three groups. One group was transfected with the sense IGFBP-4 cDNA construct listed above using lipofection reagent DOTAP (Boehringer Mannheim GmbH, Mannheim, Germany) following the manufacturer's instructions. A mixture of $15 \mu \mathrm{g}$ cDNA, $90 \mu \mathrm{g}$ DOTAP and 6000000 cells in $6 \mathrm{ml}$ incubation medium was used for each transfection procedure. Control cells were incubated with DOTAP with $15 \mu \mathrm{g}$ IGFBP-3 sense and antisense gene constructs or mixed bases (GIBCO-BRL) instead of the IGFBP-4 sense cDNA construct. Thereafter the granulosa cells were washed three times in culture medium and precultured at a concentration of 1000000 cells $/ \mathrm{ml}$ in $2 \mathrm{ml}$ culture medium (Dulbecco's modified Eagle's medium/F-12; 1:1 mixture supplemented with $10 \%$ bovine fetal serum and $1 \%$ antibioticantimicotic from Sigma, St Louis, MO, USA) in Falcon 24-well plates (Becton Dickinson, Lincoln Park, CA, USA) at $37^{\circ} \mathrm{C}$ under $5 \% \mathrm{CO}_{2}$ in humidified air. After 2 days of preculture the medium was replaced with medium of the same composition with porcine GH (pGH; USDA-pGH$\mathrm{B}-1,100 \mathrm{ng} / \mathrm{ml}$ ), porcine LH (pLH; USDA-pLHB-6, $100 \mathrm{ng} / \mathrm{ml}$ ) which were kindly provided by Dr J A Proudman (USDA Animal Hormone Program, 
TABLE 1. Characteristics of immunoassays used in experiments

\begin{tabular}{|c|c|c|c|c|}
\hline \multirow[b]{3}{*}{$\begin{array}{l}\text { Assay } \\
\text { (cross-reactivity } \\
\text { of antiserum) }\end{array}$} & \multirow[b]{2}{*}{ Specificity of assay } & \multirow{2}{*}{$\begin{array}{l}\text { Sensitivity } \\
\text { of assay } \\
(\mathrm{ng} / \mathrm{ml})\end{array}$} & \multicolumn{2}{|c|}{ Coefficient of variation $(\%)$} \\
\hline & & & Intra-assay & Interassay \\
\hline & & & & \\
\hline Progesterone & $\begin{array}{l}<0 \cdot 001 \% \text { to cortisol, } \\
\text { corticosterone, cortisol, } \\
\text { androstenediol, pregnenolone, } \\
\text { estradiol, testosterone }\end{array}$ & $0 \cdot 12$ & $<13 \cdot 1$ & $<8 \cdot 0$ \\
\hline Oxytocin & $\begin{array}{l}<0 \cdot 01 \% \text { to arg-vasopressin, } \\
\text { lys-vasopressin, arg-vasotocin, } \\
\text { somatostatin, IGF-I, IGFBP-3, } \\
\text { pGH, pLH }\end{array}$ & $0 \cdot 003$ & $<10 \cdot 5$ & $<5 \cdot 6$ \\
\hline IGF-I & $\begin{array}{l}<0 \cdot 1 \% \text { to } \mathrm{IGF}-\mathrm{II} \text {, insulin, } \\
\text { proinsulin, } \mathrm{pGH} \text {, oxytocin, } \\
\text { progesterone }\end{array}$ & $0 \cdot 027$ & $<3 \cdot 4$ & $<8 \cdot 2$ \\
\hline IGFBP-3 & $\begin{array}{l}<0 \cdot 03 \% \text { to IGFBP- } 1,-2,-4,-5 \\
-6, \text { IGF-I, pGH, pLH, oxytocin }\end{array}$ & $0 \cdot 5$ & $<3.9$ & $<1 \cdot 9$ \\
\hline
\end{tabular}

Beltsville, MD, USA), or recombinant IGF-I $(10 \mathrm{ng} / \mathrm{ml})$, synthetic oxytocin $(10 \mathrm{ng} / \mathrm{ml})$ or estradiol-17 $\beta$ (100 ng/ml) from Sigma. Control groups in each transfected and non-transfected group contained either no cells (blank control) or cells with no exogenous treatment. The experimental substances were of immunological grade. They were dissolved in medium immediately before each experiment. After 2 days in culture, the conditioned medium from each well was gently aspirated and frozen at $-18{ }^{\circ} \mathrm{C}$ to await ligand blotting and radioimmunoassay (RIA). After culture, cell number and viability were determined by Trypan blue staining and hemocytometry. No statistically significant differences in these indices between control and experimental groups were observed.

\section{Immunoassay}

Concentrations of hormones in $25-100 \mu \mathrm{l}$ incubation medium were determined by RIA/immunoradiometric (IRMA) assays with extraction of IGF-I and oxytocin, but not of IGFBP-3 and progesterone prior to assay. IGF-I, IGFBP-3 and progesterone were determined using RIA/IRMA kits from DSL (Webster, TX, USA) according to the manufacturer's instructions. Oxytocin was measured using our RIA described previously (Kotwica \& Skarzynski 1993). The characteristics of these assays are presented in Table 1 .

\section{Protein gel electrophoresis and ligand blotting}

Production of IGFBP-4 and other IGFBPs was estimated by ligand blot analysis as described by Hossenlop et al. (1986) and modified by McCusker et al. (1988). Briefly, the proteins in conditioned medium and control serum (human and fetal bovine) samples were electrophoresed in $12.5 \%$ polyacrylamide gels in the presence of SDS under non-reducing conditions (Laemmli 1970). Following electroblotting onto $0.05 \mu \mathrm{m}$ BA 75 nitrocellulose (Schleicher and Schuell, Keene, NH, USA), the blots were probed with ${ }^{125}$ I-IGF-II (Amersham, Little Chalfont, Bucks, UK). Signal intensities for radioactive bands on each blot were quantified by the use of a PhosphorImager (Molecular Dynamics, Sunnyvale, CA, USA) with the results reported in arbitrary units.

\section{Statistics}

Each experimental group was represented by four culture wells. Assays of hormone and growth factor content in the conditioned medium were performed in duplicate. The data shown are means of values obtained on granulosa cells harvested from at least 20 animals. In ligand blotting, expression of the IGFBP-4 band in medium conditioned by cells transfected with IGFBP-4 sense cDNA construct (specific transfection) was compared with this band produced by cells treated with mixed bases (control 


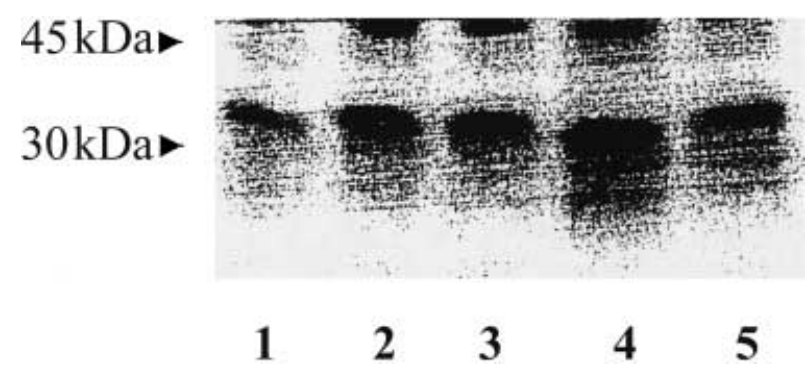

FIGURE 1. Assessment of IGFBP-4 in culture medium conditioned by porcine granulosa cells using ligand blotting. Lane 1, control cells I (transfection with mixed bases), lane 2, control cells (transfected with sense IGFBP-3 cDNA construct), lane 3, control cells (transfected with antisense IGFBP-3 cDNA construct), lane 4, experimental cells (transfected with sense IGFBP-4 cDNA construct) and lane 5, control cells (without transfection).

transfection), with IGFBP-3 sense and antisense constructs (non-specific transfection) and by intact cells (intact control). In RIA/IRMA assays, the values of substances released by cells transfected with IGFBP-4 sense cDNA construct were compared only with control cells transfected with mixed bases. The values of blank control (medium cultured without cells) were subtracted from the value determined in cell-conditioned medium to exclude any non-specific background. It did not usually exceed $10 \%$ of the total values measured in cell-conditioned medium. The rates of experimental substance secretion were calculated per $10^{6}$ viable cells/day. Significant differences between the experiments were evaluated using two-way ANOVA. When effects of treatments were revealed, data from the experimental and control groups were compared by Duncan's multiple range test. Differences from controls with a $P$ value of $<0.05$ were considered significant.

\section{RESULTS}

Accumulation of IGFBP-4 in culture medium conditioned by porcine granulosa cells was demonstrated by ligand blotting (Fig. 1). The radiolabeled band with a relative molecular weight of $30 \mathrm{kDa}$, characteristic for IGFBP-4, was located under the IGFBP-3 band $(45 \mathrm{kDa})$. No significant visible bands corresponding to any of the other IGFBPs or IGFBP-3 and -4 fragments were detected in cell-conditioned medium. Lipofection of granulosa cells with the sense IGFBP-4 (but not with sense and antisense IGFBP-3) cDNA construct resulted in a significant increase in expression of IGFBP-4 in

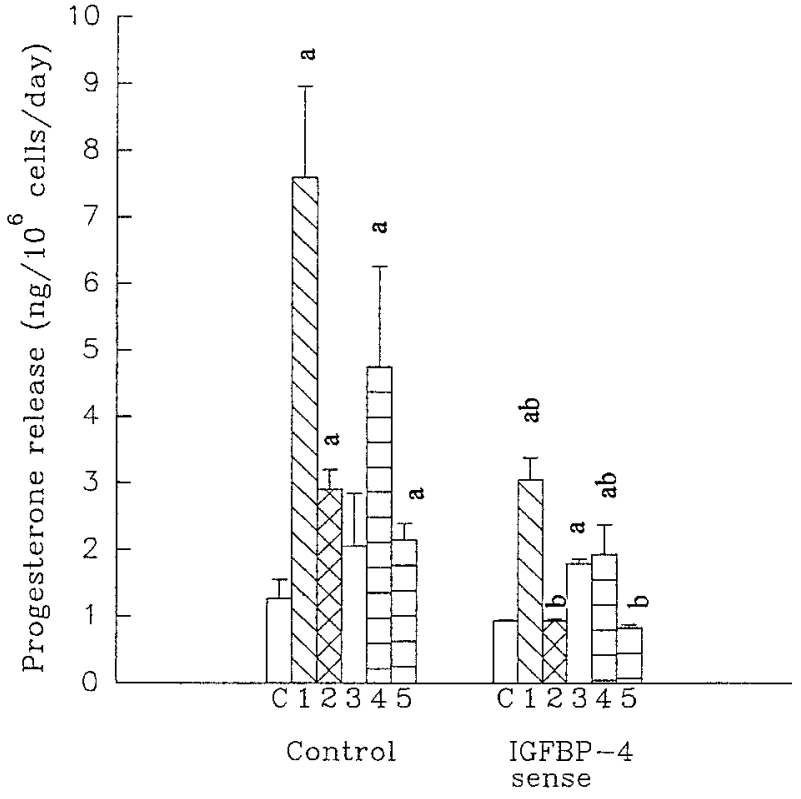

FIGURE 2. Effect of hormones and growth factor on progesterone release by cultured porcine granulosa cells not transfected (transfection with mixed bases, indicated as 'Control') and transfected with sense IGFBP-4 cDNA construct (indicated as 'IGFBP-4 sense'). C, control (cells cultured without exogenous hormones and growth factor); 1, cells cultured with pGH $(100 \mathrm{ng} / \mathrm{ml}$ medium); 2, cells cultured with IGF-I (10 ng/ml); 3, cells cultured with estradiol $(100 \mathrm{ng} / \mathrm{ml}) ; 4$, cells cultured with $\mathrm{pLH}(100 \mathrm{ng} / \mathrm{ml}) ; 5$, cells cultured with oxytocin $(10 \mathrm{ng} / \mathrm{ml})$. Values are means \pm s.E.M. ${ }^{a} P<0 \cdot 05$ compared with control (medium without exogenous hormones or growth factors); ${ }^{\mathrm{b}} \mathrm{P}<0.05$ between transfected and non-transfected cells cultured with the same treatment.

the culture medium: the radiolabeled band intensity increased from 586068 arbitrary units in control (transfected with mixed bases) cells to 1086239 arbitrary units in the experimental group. The transfection by either of the cDNA constructs had no effect on the IGFBP-3 band or on the position and structure of the IGFBP-4 bands.

The results of the RIA/IRMA assays of the conditioned medium showed that porcine granulosa cells are able to secrete significant amounts of IGF-I, IGFBP-3, oxytocin and progesterone, and that release of these substances is altered by transfection of cells with an IGFBP-4 sense cDNA construct, by exogenous hormones and by IGF-I (Figs 2-5).

Progesterone release (Fig. 2) in control cells was significantly increased by GH, IGF-I, LH and oxytocin, but not by estradiol treatment. Transfection of cells with the IGFBP-4 sense construct 


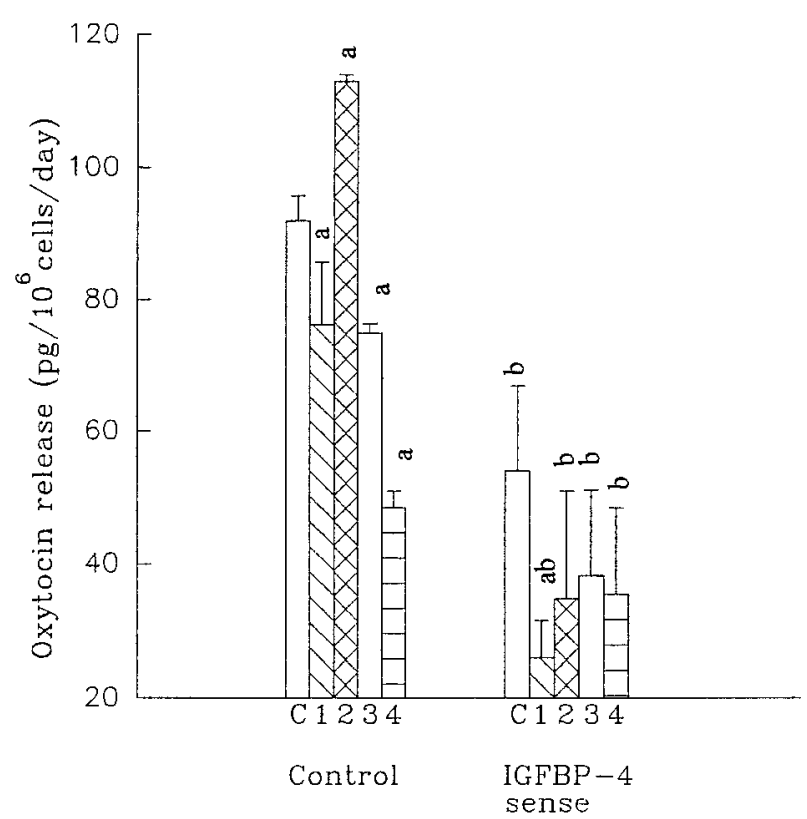

FIGURE 3. Effect of hormones and growth factor on oxytocin release by cultured porcine granulosa cells not transfected (transfection with mixed bases, indicated as 'Control') and transfected with sense IGFBP-4 cDNA construct (indicated as 'IGFBP-4 sense'). C, control (cells cultured without exogenous hormones and growth factor); 1 , cells cultured with pGH (100 ng/ml medium); 2 , cells cultured with IGF-I $(10 \mathrm{ng} / \mathrm{ml}) ; 3$, cells cultured with estradiol $(100 \mathrm{ng} / \mathrm{ml}) ; 4$, cells cultured with $\mathrm{pLH}$ $(100 \mathrm{ng} / \mathrm{ml})$. Values are means \pm s.E.M. ${ }^{\mathrm{a}} P<0 \cdot 05$ compared with control (medium without exogenous hormones or growth factors); ${ }^{\mathrm{b}} \mathrm{P}<0 \cdot 05$ between transfected and non-transfected cells cultured with the same treatment.

significantly decreased basal, hormonal- and growth factor-induced progesterone release.

Oxytocin release (Fig. 3) in control cells was significantly suppressed by GH, estradiol and LH, while IGF-I significantly increased oxytocin release. Cells transfected with the IGFBP-4 sense construct had a significant inhibition of both basal, hormonal- and growth factor-induced oxytocin release.

IGF-I release (Fig. 4) was not substantially affected by the exogenous hormones, but transfection of the cells with the IGFBP-4 sense construct significantly increased the basal IGF-I release. Furthermore, IGFBP-4-transfected cells cultured with hormones produced significantly more IGF-I than control cells and the inhibitory influence of LH and oxytocin on IGF-I release was still expressed in these transfected cells.

IGFBP-3 release (Fig. 5) was stimulated by IGF-I and LH, and inhibited by GH and oxytocin,

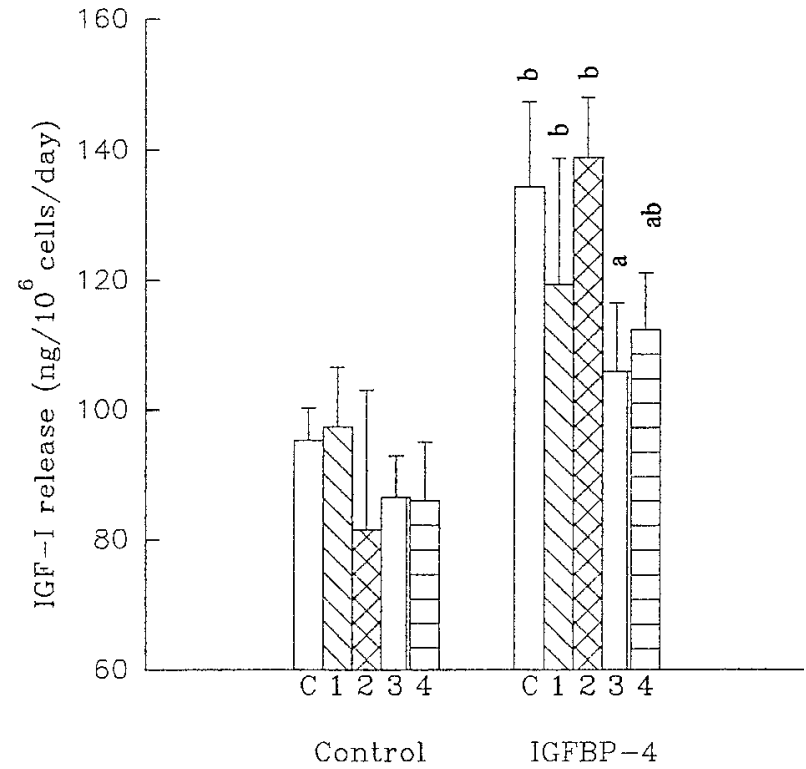

FIGURE 4. Effect of hormones and growth factor on IGF-I release by cultured porcine granulosa cells not transfected (transfection with mixed bases, indicated as 'Control') and transfected with sense IGFBP-4 cDNA construct (indicated as 'IGFBP-4 sense'). C, control (cells cultured without exogenous hormones and growth factor); 1 , cells cultured with pGH (100 ng/ml medium); 2 , cells cultured with estradiol $(100 \mathrm{ng} / \mathrm{ml}) ; 3$, cells cultured with pLH $(100 \mathrm{ng} / \mathrm{ml}) ; 4$, cells cultured with oxytocin $(10 \mathrm{ng} / \mathrm{ml})$. Values are means \pm s.E.M. ${ }^{\text {a }} P<0 \cdot 05$ compared with control (medium without exogenous hormones or growth factors); ${ }^{\mathrm{b}} \mathrm{P}<0 \cdot 05$ between transfected and non-transfected cells cultured with the same treatment.

but not by estradiol. Transfection of cells with the IGFBP-4 sense construct reduced the IGFBP-3 release in cells cultured with and without hormones and growth factors. In the transfected cells, GH, LH and oxytocin stimulated IGFBP-3 release, while IGF-I and estradiol suppressed it; however, in these cells, both the absolute IGFBP-3 secretion rate and the response to each treatment was reduced.

\section{DISCUSSION}

The results of the RIAs confirmed previous reports (Wathes 1989, Spicer \& Echternkamp 1995, Sirotkin 1996, Sirotkin et al. 1998) of the production of IGFBP-3, IGF-I, oxytocin and progesterone by cultured porcine ovarian cells, and of the involvement of GH, IGF-I, estradiol, LH and oxytocin in the control of this process. On the other hand, failure of $\mathrm{GH}$, estradiol, $\mathrm{LH}$ and 


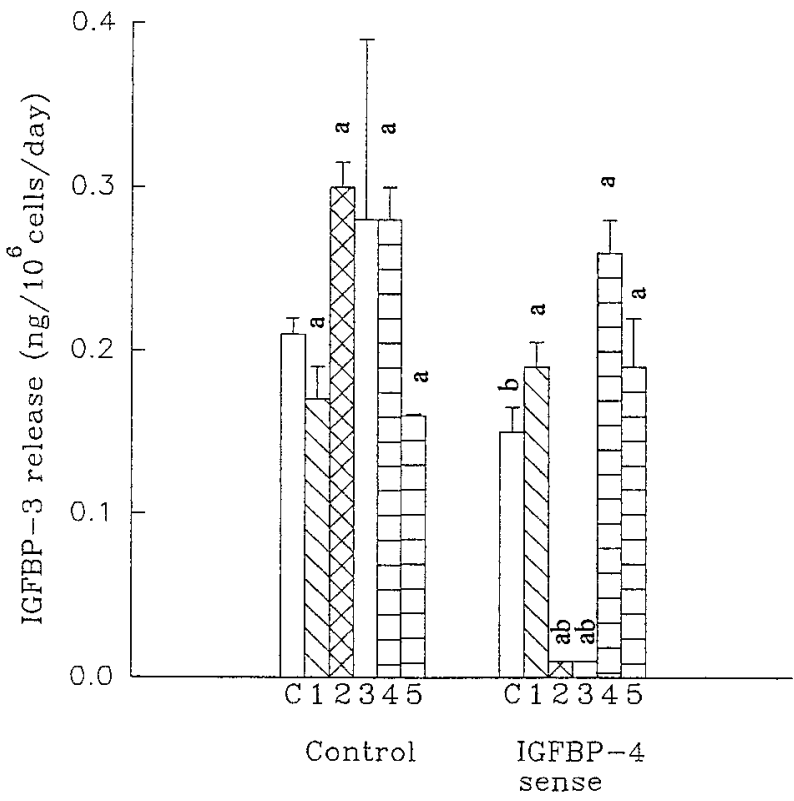

FIGURE 5. Effect of hormones and growth factor on IGFBP-3 release by cultured porcine granulosa cells not transfected (transfection with mixed bases, indicated as 'Control') and transfected with sense IGFBP-4 cDNA construct (indicated as 'IGFBP-4 sense'). C, control (cells cultured without exogenous hormones and growth factor); 1, cells cultured with pGH (100 ng/ml medium); 2 , cells cultured with IGF-I $(10 \mathrm{ng} / \mathrm{ml}) ; 3$, cells cultured with estradiol $(100 \mathrm{ng} / \mathrm{ml}) ; 4$, cells cultured with $\mathrm{pLH}$ $(100 \mathrm{ng} / \mathrm{ml}) ; 5$, cells cultured with oxytocin $(10 \mathrm{ng} / \mathrm{ml})$. Values are means \pm s.E.M. ${ }^{\text {a }} P<0 \cdot 05$ compared with control (medium without exogenous hormones or growth factors); ${ }^{\mathrm{b}} \mathrm{P}<0.05$ between transfected and non-transfected cells cultured with the same treatment.

oxytocin to influence IGF-I release in control cells and the inhibitory effect of $\mathrm{LH}$ and oxytocin on IGF-I output in transfected cells differs from previous reports of a stimulatory action of these substances on IGF-I. These discrepancies may be due to differences in cell origin, state and luteinization rate in different experiments. The amounts of progesterone, oxytocin, IGF-I and IGFBP-3 produced by control cells and cells transfected in our experiments are comparable to those described previously in non-transfected porcine granulosa cells.

Results of our ligand blotting confirm a previous report (Grimes et al. 1994) of the production of IGFBP-4 by porcine ovarian cells. The $30 \mathrm{kDa}$ band detected in our experiments corresponds to the IGFBP species detected by these authors by ligand, Western and Northern blotting, and corresponds to the glycosylated form of IGFBP-4. Furthermore, our results demonstrated that the transfection of cultured granulosa cells with an IGFBP-4 sense construct (but not with IGFBP-3 sense and antisense construct or mixed bases) produced an increase in IGFBP-4 release, providing validation of the efficiency and specificity of our transfection procedure.

This is the first reported study on the role of ovarian IGFBP-4 in mammalian reproduction utilizing a recombinant transfection to alter native secretion of this growth factor. These data suggest that IGFBP-4 is involved in the control of the release of various ovarian products - a steroid hormone (progesterone), a nonapeptide hormone (oxytocin), IGF-I and IGFBP-3.

Our observation of transfection-induced suppression of basal, IGF-I- and LH-stimulated progesterone release corresponds to the reported effects of exogenous IGFBP-4 (rat: Putowski et al. 1997, humans: Mason et al. 1998), gonadotropins (pig: Grimes et al. 1994, rat: Putowski et al. 1997, cow: Armstrong et al. 1996, 1998, Mihm et al. 1997) and IGF-I (pig: Grimes et al. 1994, humans: Iwashita et al. 1996, sheep: Armstrong et al. 1996) additions and their combinations. These studies and the data in the literature suggest that IGFBP-4 may be a physiological inhibitor of basal, gonadotropin- and IGF-I-induced progesterone release by mammalian ovaries. Our observations seems to be the first data showing that IGFBP-4 can inhibit the effects of $\mathrm{GH}$, estradiol and oxytocin on this steroid.

The observation of an inhibitory effect of IGFBP-4 overexpression on the basal, hormonaland IGF-I-regulated oxytocin and IGFBP-3 release is, to our knowledge, the first demonstration of the involvement of IGFBP-4 in the control of ovarian nonapeptide hormones and of other IGFBPs. Both oxytocin and IGFBP-3 are important regulators of the reproductive processes (Wathes 1989, Erickson 1995, Spicer \& Echternkamp 1995, Sirotkin et al. 1998, Schams et al. 1999). Therefore, IGFBP-4 can potentially control ovarian functions through its influence on local oxytoxin and/or IGFBP-3. This hypothesis is supported by the present observation that addition of oxytocin fully or partially prevented the effects of IGFBP-4 overexpression on IGFBP-3 and IGF-I release. The effect of IGFBP-4 on progesterone release is probably not mediated by oxytocin because exogenous oxytocin was unable to eliminate the action of IGFBP-4 on progesterone.

The potential mediator of IGFBP-4 action on ovarian functions (including basal and hormonestimulated progesterone and oxytocin release) might be IGF-I: IGFBPs are able to bind endogenous IGF-I, the presence of which could be required for the maintenance of ovarian secretory activity and ovarian response to stimulators. Our observations 
that an IGFBP-4 transfection-induced inhibition of the IGF-I effects on progesterone, oxytocin and IGFBP-3 release support the previous evidence of an inhibitory influence of IGFBP-4 on ovarian IGF-I action (formation of inactive IGF/IGFBP complex, prevention of IGF-I binding and action on ovarian receptors; Spicer \& Echternkamp 1995, Iwashita et al. 1996, Spicer \& Chamberlain 1999). On the other hand, our data suggest that IGFBP-4 can inhibit ovarian function via the blockade of IGF-I action but not by the blockade of IGF-I expression because, in our experiments, the addition of IGF-I itself was not able to overcome the inhibitory effects of IGFBP-4 on progesterone, oxytocin and IGFBP-3. Furthermore, our observation of a transfection-induced increase in IGF-I release by cells cultured with and without various hormones demonstrates the stimulatory action of IGFBP-4 on ovarian IGF-I release. The reasons for and physiological significance of IGFBP-4stimulated IGF-I release remain to be studied, but the protective role of IGFBP-4 against IGF-I degradation or the feedback effect of an IGFBP-4induced blockade of the effects of IGF-I, which could induce an additional IGF-I surge, could be proposed.

An additional mechanism whereby IGFBPs may be involved in the control of ovarian function includes changes in IGFBP proteolysis: IGF-I (Myers et al. 1993, Grimes \& Hammond 1994, Iwashita et al. 1998) and FSH (Iwashita et al. 1998, Resnik et al. 1998) can alter the proteolysis of IGFBPs and, therefore, the binding of IGFBPs to IGF with a resultant change in the local level of bioavailable IGF.

The complex inter-relationships between IGFBP-4 and IGF-I require further elucidation, but our present observations suggest that IGFBP-4 can inhibit the effects of IGF-I but, on the other hand, stimulate IGF-I release. The significance and mechanisms of IGFBP-4 action on various ovarian functions require further detailed studies. Nevertheless, our approach suggests that IGFBP-4 can be a mediator of some hormonal actions on the ovary and a potent regulator of ovarian secretory activity, specifically steroid, nonapeptide hormone, growth factor and growth factor-binding protein release.

\section{ACKNOWLEDGEMENTS}

We express our gratitude to Dr S Shimasaki (The Whittier Institute for Diabetes and Endocrinology) for the generous gift of IGFBP-4 cDNA, Dr J A Proudman (USDA Animal Hormone Program) for kindly providing the $\mathrm{pGH}$ and $\mathrm{pLH}, \mathrm{Dr} \mathrm{G}$ Kotwica (University of Agriculture and Technology, Olsztyn, Poland) for donation of the antiserum against oxytocin, Ing L Hetényi for permanent support of these studies, and $\mathrm{T}$ Civan̆ová, $\mathrm{K}$ Tothová, M Bláhova and $\mathrm{B}$ Ustianovska for technical assistance.

\section{REFERENCES}

Armstrong DG, Hogg CO, Campbell BK \& Webb R 1996 Insulin-like growth factor (IGF)-binding protein production by primary cultures of ovine granulosa and theca cells. The effects of IGF-I, gonadotropins, and follicular size. Biology of Reproduction $\mathbf{5 5}$ 1163-1171.

Armstrong DG, Baxter G, Gutierrez CG, Hogg CO, Glazyrin AL, Campbell BK, Bramley TA \& Webb R 1998 Insulinlike growth factor binding protein-2 and -4 messenger ribonucleic acid expression in bovine ovarian follicles: effect of gonadotropins and developmental status. Endocrinology 139 2146-2154.

Cohen P, Lamson G, Okajima T \& Rosenfeld RG 1993 Transfection of the insulin-like growth factor binding protein-3 gene into Balb/c fibroblasts inhibits cellular growth. Molecular Endocrinology 7 380-386.

Corkins MR, Vanderhoof JA, Caruso NM, Hrbek MJ, Schaffer BS, Slentz DH, McCusker RH \& MacDonald RG 1995 Growth stimulation by transfection of intestinal epithelial cells with an antisense insulin-like growth factor binding protein-2 construct. Biochemical and Biophysical Research Communications 211 707-713.

Erickson GF 1995 The ovarian connections. In Reproductive Endocrinology, Surgery and Technology, pp 1141-1160. Eds E Adashi, JA Rock \& Z Rosenwars. New York: Raven Press.

Grimes RW \& Hammond JM 1994 Proteolytic degradation of insulin-like growth factor (IGF)-binding protein-3 by porcine ovarian granulosa cells in culture: regulation by IGF-I. Endocrinology 134 337-343.

Grimes RW, Barber JA, Shimasaki S, Ling A \& Hammond JM 1994 Porcine ovarian granulosa cells secrete insulin-like growth factor-binding proteins- 4 and -5 and express their messenger ribonucleic acids: regulation by follicle-stimulating hormone and insulin-like growth factor-1. Biology of Reproduction 50 695-701.

Hossenlop P, Seurin D, Segovia-Quinson B, Hardouin S \& Binoux M 1986 Analysis of serum insulin-like growth factor binding proteins using western blotting: use of the method for titration of the binding proteins and competitive binding studies. Analytical Biochemistry 154 138-143.

Iwashita M, Kudo Y, Yoshimura Y, Adashi T, Katayama E \& Takeda Y 1996 Physiological role of insulin-like growth factor binding protein-4 in human folliculogenesis. Hormone Research 46 31-36.

Iwashita M, Kudo Y \& Takeda Y 1998 Effect of follicle stimulating hormone and insulin-like growth factors on proteolysis of insulin-like growth factor binding protein-4 in human granulosa cells. Molecular Human Reproduction 4 401-405.

Kotwica J \& Skarzynski D 1993 Influence of oxytocin removal from the corpus luteum on secretory function and duration of the oestrous cycle in cattle. Fournal of Reproduction and Fertility 97 411-417.

Laemmli UK 1970 Cleavage and structure of proteins during the assembly of the head of bacteriophage T4. Nature 227 680-685. 
McCusker RH, Champion DR \& Clemmons DR 1988 The ontogeny and regulation of a $31000 \mathrm{M}_{\mathrm{r}}$ insulin-like growth factor/somatomedin (IGF) binding protein in fetal porcine plasma and sera. Endocrinology 122 3071-3079.

Mason HD, Cwyfan-Hughes S, Holly JM \& Franks S 1998 Potent inhibition of human steroidogenesis by insulin-like growth factor binding protein-4 (IGFBP-4). Fournal of Clinical Endocrinology and Metabolism 83 284-287.

Mihm M, Good TE, Ireland JL, Ireland JJ, Knight PG \& Roche JF 1997 Decline in serum follicle-stimulating hormone concentrations alters key intrafollicular growth factors involved in selection of the dominant follicle in heifers. Biology of Reproduction 57 1328-1337.

Myers SE, Cheung PT, Handwerger S \& Chemausek SD 1993 Insulin-like growth factor-I (IGF-I) enhances proteolysis of IGF-binding protein-4 in conditioned medium from primary cultures of human decidua: independence from IGF receptor binding. Endocrinology 133 1525-1531.

Park JHY, Corkins MR, Vanderhoof JA, Caruso NM, Hrbek MJ, Schaffer BS, Slentz DH, McCusker RH \& MacDonald RG 1996 Expression of insulin-like growth factor-II and insulin-like growth factor binding proteins during Caco-2 cell proliferation and differentiation. Fournal of Cell Physiology 166 396-406.

Putowski L, Rohan RM, Choi DS, Scherzer WJ, Ricciarelli E, Mordacq J, Mayo KE \& Adashi EY 1997 Rat ovarian insulin-like growth factor binding protein-4: a hormonedependent granulosa cell-derived antigonadotropin. Fournal of Society for Gynecological Investigations 4 144-151.

Rajaram S, Baylink DJ \& Mohan S 1997 Insulin-like growth factor-binding proteins in serum and other biological fluids: regulation and functions. Endocrine Reviews 18 801-831.

Rechler MW \& Clemmons DR 1998 Regulatory actions of insulin-like growth factor-binding proteins. Trends in Endocrinology and Metabolism 9 176-183.

Resnik CE, Fielder PJ, Rosenfeld RG \& Adashi EY 1998 Characterization and hormonal regulation of a rat ovarian insulin-like growth factor binding protein-5 endopeptidase: an FSH-inducible granulosa cell-derived metalloproteinase. Endocrinology 139 1249-1252.

Samaras SE \& Hammond JM 1995 Insulin-like growth factor binding protein-3 inhibits porcine granulosa cell function in vitro. American Fournal of Physiology 268 E1057-E1064.
Schams D, Berisha B, Kosmann M, Einspanier R \& Amselgruber WM 1999 Possible role of growth hormone, IGFs, and IGF-binding proteins in the regulation of ovarian function in large farm animals. Domestic Animal Endocrinology 17 279-285.

Shimasaki S, Koba A, Mercado M, Shimonaka M \& Ling N 1989 Complementary DNA structure of the high molecular weight rat insulin-like growth factor binding protein (IGFBP-3) and tissue distribution of its mRNA. Biochemical and Biophysical Research Communications 165 907-912.

Sirotkin A 1996 Direct action of growth hormone on bovine ovarian cells: effects on estradiol, oxytocin, vasopressin secretion by granulosa cells and on oocyte maturation and cleavage in vitro. Annales d'Endocrinologie 57 219-224.

Sirotkin AV \& Makarevich AV 1999 GH regulates secretory activity and apoptosis in cultured bovine granulosa cells through the activation of the $\mathrm{cAMP} /$ protein kinase A system. Fournal of Endocrinology 163 317-327.

Sirotkin AV, Makarevich AV, Kotwica J, Marnet P-G, Kwon HB \& Hetenyi L 1998 Isolated porcine ovarian follicles as a model for the study of hormone and growth factor action on ovarian secretory activity. Fournal of Endocrinology 159 313-321.

Spicer LJ \& Chamberlain CS 1999 Insulin-like growth factor binding protein-3: its biological effect on bovine granulosa cells. Domestic Animal Endocrinology 16 19-29.

Spicer LJ \& Echternkamp SE 1995 The ovarian insulin-like growth factor system with an emphasis on domestic animals. Domestic Animal Endocrinology 12 223-245.

Spicer LJ, Stewart RE, Alvarez P, Francisco CC \& Keefer BE 1997 Insulin-like growth factor-binding protein-2 and -3: their biological effects in bovine thecal cells. Biology of Reproduction 56 1458-1465.

Wathes DC 1989 Oxytocin and vasopressin in the gonads. Oxford Reviews of Reproductive Biology 11 226-283.

Yoshimura Y 1998 Insulin-like growth factors and ovarian physiology. Fournal of Obstetrics and Gynaecology Research 24 305-323.

RECEIVED 20 November 2000

ACCEPTED 7 January 2001 